\title{
Isolation of novel microsatellite markers from Paralichthys lethostigma (Paralichthyidae) and their cross-species application in Pleuronectiformes
}

\author{
Y.-J. Xu, M.-J. Liao, Y.-G. Wang, Z.-C. Liu, P. Qin, Z. Zhang, X.-J. Rong \\ and X.-Z. Liu \\ Qingdao Key Laboratory for Marine Fish Breeding and Biotechnology, \\ Yellow Sea Fisheries Research Institute, Chinese Academy of Fishery Sciences, \\ Qingdao, China \\ Corresponding author: X.-Z. Liu \\ E-mail: liuxz@ysfri.ac.cn
}

Genet. Mol. Res. 12 (4): 6767-6772 (2013)

Received January 25, 2013

Accepted July 17, 2013

Published December 16, 2013

DOI http://dx.doi.org/10.4238/2013.December.16.2

\begin{abstract}
We investigated the genetic diversity of the southern flounder Paralichthys lethostigma. Microsatellite-enriched libraries were constructed and novel microsatellite markers were developed and applied for genetic detection of wild populations. Cross-species amplification was also conducted in five pleuronectiforme species. Of 45 randomly selected and sequenced clones, 43 contained a CA or GA repeat motif. Fourteen pairs of primers were designed to investigate the polymorphism and genetic structure of a wild population collected from North Carolina State coastal waters. Two loci were monomorphic and 12 loci were polymorphic. The number of alleles per polymorphic locus ranged from 2 to 16, with an average of 7.3, and the expected heterozygosity per locus ranged from 0.10 to 0.92 , with an average of 0.58 . Crossspecies amplification showed that most of the markers could successfully amplify Paralichthys olivaceus DNAs, few markers amplified in
\end{abstract}


Verasper variegatus and Verasper moseri, and none of them could amplify Scophthatmus maximus and Cynoglossus semilaevis DNAs. The isolated polymorphic markers would be useful for the genetic breeding and assessment of genetic variation within the genus Paralichthys.

Key words: Paralichthys lethostigma; Microsatellite marker; Cross-species amplification; Pleuronectiformes

\section{INTRODUCTION}

Southern flounder, Paralichthys lethostigma, is an ecologically and commercially important large benthic flatfish inhabiting coastal waters of United States, which supports recreational and commercial fisheries (Froeschke et al., 2011; Renshaw et al., 2012). Farming southern flounder for food and recreational purposes started in the 1990s (Smith et al., 1999a,b; Jenkins and Smith, 1999), and now a stable spawning and seedling production technique has been established (Watanabe et al., 2006). We introduced southern flounder to China from North Carolina, USA, in 2002 (Liu et al., 2007). Its unusual ability to grow well in freshwater (Bai and Lin, 2006) and wide temperature tolerance made it a promising species for aquaculture.

To maintain long-term resource sustainability and provide a sustainable development of the aquaculture of this species, resource enhancement and genetic management of southern flounder should be carried out to assess reductions in population sizes and to aid efforts in marker-assisted selection and broodstock improvement. On the other hand, this species exhibits a sex-biased growth pattern, in which the females show better growth than males (Liu et al., 2007). Thus, all-female production by chromosome set manipulation or sex control is both of theoretical interest and economic importance. Therefore, the basic genetic information of southern flounder populations is highly required.

To study the genetic composition and variation of populations, one needs polymorphic molecular markers, such as microsatellites. Of all the molecular marker types, microsatellite markers have proven to be an extremely valuable tool for genetic study and the conservation and management of genetic resources. To date, few microsatellite sequences have been made available in GenBank and reported by other researchers (Shao et al., 2008; Renshaw et al., 2012), which has limited the assessment of the population structure, molecular phylogeny and molecular-assisted selective breeding in this marine fish species. Thus, the development of new microsatellite markers in southern flounder is very important for analyzing genome organization and evolution and for developing molecular breeding techniques.

In the present study, we developed 12 novel polymorphic microsatellite loci for southern flounder. The level of polymorphism for these markers was evaluated. Additionally, the cross utility of these markers was tested in five other flatfish species.

\section{MATERIAL AND METHODS}

\section{DNA extraction}

Thirty individuals of P. lethostigma were collected from the Center for Marine Science, University of North Carolina Wilmington, USA $\left(34^{\circ} 08^{\prime} \mathrm{N}, 77^{\circ} 52^{\prime} \mathrm{E}\right)$. Fin clips were 
sampled and genomic DNA was extracted from alcohol-preserved muscle tissues using the phenol-chloroform method as modified by Taggart et al. (1992). The extracted genomic DNA was stored at $-20^{\circ} \mathrm{C}$ until genotyping.

\section{Microsatellite-enriched library construction}

Microsatellite-enriched library was conducted using the "fast isolation by amplified fragment length polymorphism of sequences containing repeats" method described in detail by Zane et al. (2002), with minor modification. Genomic DNA was digested with $\mathrm{Mse}$ I at $37^{\circ} \mathrm{C}$ for $3 \mathrm{~h}$ and ligated with a synthesized $M s e$ I adaptor (5'-TAC TCA GGA CTC AT-3'/5'-GAC GAT GAG TCC TGA G-3') using $T_{4}$ DNA ligase (Sangon, Shanghai, China). The digestion-ligation mixture was amplified using the adaptor-specific primer (5'-GAT GAG TCC TGA GTA A-3'). Microsatellite-containing fragments were selectively enriched, captured and washed using biotinylated (CA) $)_{12}$ or biotinylated $(\mathrm{GA})_{12}$ and Streptavidin Magne Sphere ${ }^{\circledR}$ Paramagnetic Particles (Promega, USA). Fragments containing microsatellites were ligated with the pMD18-T (TaKaRa, Dalian, China) vector and transformed into competent Escherichia coli JM109 cells (TaKaRa) by electroporation.

\section{Isolation of microsatellite-containing DNA fragments and primer design}

Each recombinant was subjected to three individual polymerase chain reaction (PCR) screenings using two universal sequencing primers and $(\mathrm{CA})_{12} \mathrm{DN}$ oligonucleotide to check whether the microsatellite motif was located in the middle of the insert. In the first reaction, universal forward and universal reverse sequencing primers were used; in the second reaction, universal forward sequencing primer and $(\mathrm{CA})_{12} \mathrm{DN}$ oligonucleotide were used; in the third reaction, universal reverse sequencing primer and $(\mathrm{CA})_{12} \mathrm{DN}$ oligonucleotide were used. Recombinant clone-producing products of obviously different length between the first reaction and the second or the third reaction were sequenced and trimmed. The SSRHunter V1.3 software was used to scan the sequencing data (Li and Wan, 2005). Sequences with microsatellite motifs and flanking regions were selected for PCR primer design using the Primer Premier software (PREMIER Biosoft International, 2009).

\section{PCR amplification and genotyping}

The microsatellite primers designed were used to amplify genomic DNA of $30 P$. lethostigma individuals, 10 Paralichthys olivaceus individuals, 10 Verasper variegatus individuals, 10 Verasper moseri individuals, 10 Scophthatmus maximus individuals, and 10 Cynoglossus semilaevis individuals. The PCR mixture contained $0.25 \mathrm{U}$ Taq DNA polymerase (TaKaRa), $1 \mathrm{X}$ buffer, $1.5 \mathrm{mM} \mathrm{MgCl}_{2}, 200 \mu \mathrm{M}$ dNTP (each), $200 \mu \mathrm{M}$ primers (each direction), and about $50 \mathrm{ng}$ genomic DNA. The PCR conditions were denaturation at $94^{\circ} \mathrm{C}$ for $1 \mathrm{~min}$, followed by 30 cycles of $1 \mathrm{~min}$ at $94^{\circ} \mathrm{C}, 1 \mathrm{~min}$ at annealing temperature, and $1 \mathrm{~min}$ at $72^{\circ} \mathrm{C}$, with a final extension for $5 \mathrm{~min}$ at $72^{\circ} \mathrm{C}$. The optimized annealing temperatures of different primer pairs are listed in Table 1 . The PCR product was separated on $6 \%$ denaturing polyacrylamide gel and visualized by silver staining. Allele size was determined using the Quantity One V4.62 software (Bio-Rad, USA) by referring to a 20-bp DNA ladder marker (TaKaRa). 


\begin{tabular}{|c|c|c|c|c|c|}
\hline Locus & Accession No. & Repeat motif & Primer sequence $\left(5^{\prime} \rightarrow 3^{\prime}\right)$ & $\operatorname{Tm}\left({ }^{\circ} \mathrm{C}\right)$ & Expected size \\
\hline BCA27 & JF502035 & $(\mathrm{AC})_{23}$ & $\begin{array}{l}\text { F: ACAGTGAGCAGGAAGCCATTAT } \\
\text { R: CTGGGTGTAAACCTGAGGAGTG }\end{array}$ & 57 & 279 \\
\hline BCA50 & JF502039 & $(\mathrm{CA})_{12}$ & $\begin{array}{l}\text { F: CAGATACAGTCCCTCAGCGTTAC } \\
\text { R: GACTGCCGCCATTTAGCC }\end{array}$ & 54 & 88 \\
\hline BCA52 & JF502040 & $(\mathrm{AC})_{22}$ & $\begin{array}{l}\text { F: ACGATGACTGGGCTGTGAG } \\
\text { R: TGGATGGGTAATGGGATAG }\end{array}$ & 57 & 182 \\
\hline BCA65 & JF502041 & $(\mathrm{AC})_{4} \mathrm{AA}(\mathrm{AC})_{4}$ & $\begin{array}{l}\text { F: GCTTGTTATCCCTCTTTCTGT } \\
\text { R: GAGTGGTGCTCATGTTGTTT }\end{array}$ & 54 & 146 \\
\hline BCA68 & JF502042 & $(\mathrm{CA})_{7}$ & $\begin{array}{l}\text { F: GCATAGAAGACGGCGCAGAC } \\
\text { R: CAGCGTTATTGCCTCTTGTCA }\end{array}$ & 57 & 118 \\
\hline BCA70 & JF502044 & $(\mathrm{AC})_{14}$ & $\begin{array}{l}\text { F: TTCCAAAACCCAATGATGC } \\
\text { R: AGAAAAAAGGAAAATATGTGGTC }\end{array}$ & 54 & 366 \\
\hline BCA83 & JF502045 & $(\mathrm{AC})_{5}$ & $\begin{array}{l}\text { F: CATATTTCACGACTTTTCCTGCC } \\
\text { R: CCATCCCACCCTCCTTGACT }\end{array}$ & 57 & 153 \\
\hline BCA84 & JF502046 & $(\mathrm{AC})_{7}$ & $\begin{array}{l}\text { F: ACCACTGAGCCACAACCACCA } \\
\text { R: GGCTTTGTCCGCCACATCCT }\end{array}$ & 57 & 112 \\
\hline GA5 & JF502048 & $(\mathrm{GA})_{6}$ & $\begin{array}{l}\text { F: GAATCCGATATGTTTTATGACCT } \\
\text { R: GCAAAGTTTAGGAACCACCA }\end{array}$ & 54 & 220 \\
\hline GA12 & JF502050 & $(\mathrm{AG})_{9} \mathrm{AA}(\mathrm{AT})_{6}$ & $\begin{array}{l}\text { F: CCCGTACTCCATCCAATCA } \\
\text { R: TGTCTACTTTTCAGCAATCCA }\end{array}$ & 57 & 188 \\
\hline GA13 & JF502051 & $(\mathrm{GA})_{7}$ & $\begin{array}{l}\text { F: CCCTGGCGATGAGGAAAT } \\
\text { R: GCCGTGCTGAATAATAGATGC }\end{array}$ & 54 & 90 \\
\hline GA31 & JF502053 & $(\mathrm{AG})_{5} \mathrm{GC}(\mathrm{AG})_{4}$ & $\begin{array}{l}\text { F: GCAACAACATCAAAGACCCAGA } \\
\text { R: TTCCTAAACCGATTCCCTCCA }\end{array}$ & 57 & 180 \\
\hline GA34 & JF502054 & $(\mathrm{GA})_{9} \ldots(\mathrm{AG})_{5}$ & $\begin{array}{l}\text { F: ATTGTGAAAGGGATCAAGGGTG } \\
\text { R: GTGTTTCCTTCTGTATTGTTCCCA }\end{array}$ & 54 & 133 \\
\hline GA94 & JF502058 & $(\mathrm{CA})_{17}$ & $\begin{array}{l}\text { F: TACAACCAACCCCTCCATTATTT } \\
\text { R: GCTGGTCTCACATCGTTCACTG }\end{array}$ & 54 & 141 \\
\hline
\end{tabular}

\section{Genetic data analysis}

The Popgene version 1.32 software (Yeh et al., 1999) was used to calculate the number of alleles $\left(N_{\mathrm{A}}\right)$, the number of effective alleles $\left(N_{\mathrm{E}}\right)$, observed heterozygosity $\left(H_{\mathrm{O}}\right)$, and expected heterozygosity $\left(H_{\mathrm{E}}\right)$. Polymorphism information content (PIC) of each locus was calculated according to Botsein et al. (1980). Hardy-Weinberg equilibrium (HWE) and linkage disequilibrium tests were conducted using the Genepop online version (Rousset, 2008). Significance criteria of all multiple tests were corrected following the sequential Bonferroni correction (Rice, 1989).

\section{RESULTS AND DISCUSSION}

Two microsatellite-enriched libraries, (CA) enriched and (GA) enriched, were constructed using this method. One hundred randomly selected recombinant clones were selected from each library. A total of 48 clones $(48 \%)$ in the (CA) library and 38 clones $(38 \%)$ in the (GA) library were found to contain inserts with a microsatellite motif in the middle position indicating that the enrichment was highly effective. Of the 86 clones surviving PCR screening, 45 clones were sequenced, which revealed that $43(95.5 \%)$ contained a microsatellite motif in the middle position (Table 2). According to classification rules from Weber (1990), the sequences were divided into three categories: 26 perfect repeat sequences without interruptions in the runs of CA or GA dinucleotides (60.5\% of total), 14 imperfect repeat sequences with one or more interruptions in the run of repeats $(32.6 \%)$, and 3 compound repeat sequences 
with adjacent tandem simple repeats of a different sequence (6.9\%). When classified using the repeat sequence type, the repeat number of 15 clones was between 5 to 9 , and for 28 clones, it was higher than 10.

Table 2. Classification of microsatellite DNA sequences obtained from Paralichthys lethostigma in this study.

\begin{tabular}{llcr}
\hline Criterion & Category & No. of sequences & Percentage (\%) \\
\hline Weber (1990) & Perfect & 26 & 60.5 \\
& Imperfect & 14 & 32.6 \\
\multirow{2}{*}{ Repeat motif } & Compound & 3 & 6.9 \\
& Two bases $5 \leq \mathrm{n} \leq 9$ & 15 & 34.9 \\
\hline
\end{tabular}

In the first batch, 14 pairs of primers (Table 1) were designed according to 20 sequences and used to investigate the polymorphism of 30 wild southern flounder individuals collected from the Center for Marine Science, University of North Carolina Wilmington, USA. All of the tested 14 primer pairs showed clear band patterns. Two loci (BCA65 and GA13) were monomorphic and twelve markers were polymorphic (Table 3). A total of 87 alleles were detected at the 12 polymorphic loci and the total effective allele numbers was 52 . The $N_{\mathrm{A}}$ at each locus ranged from 2 (BCA65 and GA13) to 16 (BCA27) with an average of 7.3. The $N_{\mathrm{E}}$ ranged from 1.1 (BCA65 and GA13) to 10.3 (GA94) with an average of 4.3. The difference between $N_{\mathrm{A}}$ and $N_{\mathrm{E}}$ was caused by the uneven frequency of each allele. The $H_{\mathrm{O}}$ of each locus ranged from 0 (GA13) to 0.67 (BCA27) with an average of 0.35, and the $H_{\mathrm{E}}$ of each locus ranged from 0.10 (BCA65) to 0.92 (GA94) with an average of 0.58. According to the PIC value of each locus, two loci (BCA65 and GA13) were low polymorphic loci (PIC < 0.25), four loci (BCA68, BCA83, GA5, and GA31) were moderately polymorphic $(0.25<\mathrm{PIC}<$ 0.5 ), and the other six markers (BCA27, BCA52, BCA70, BCA84, GA34, and GA94) were highly polymorphic (PIC $>0.5$ ). None of the loci showed significant linkage disequilibrium. After sequential Bonferroni correction for multiple tests, three loci were found to depart significantly from HWE. Further tests indicated that heterozygote deficiency at these loci was responsible for the departure. Another possible explanation for the departure from HWE could be a dramatic decline in spawning populations and non-random mating or genetic bottlenecks.

\begin{tabular}{|c|c|c|c|c|c|c|c|c|c|c|c|c|}
\hline Locus & $\begin{array}{l}\text { Size range } \\
\text { (bp) }\end{array}$ & $N_{\mathrm{A}}$ & $N_{\mathrm{E}}$ & $H_{\mathrm{O}}$ & $H_{\mathrm{E}}$ & PIC & $\mathrm{P}$ & $\begin{array}{c}\text { Paralichthys } \\
\text { olivaceus }\end{array}$ & $\begin{array}{c}\text { Verasper } \\
\text { variegatus }\end{array}$ & $\begin{array}{c}\text { Verasper } \\
\text { moseri }\end{array}$ & $\begin{array}{l}\text { Scophthatmus } \\
\text { maximus }\end{array}$ & $\begin{array}{c}\text { Cynoglossus } \\
\text { semilaevis }\end{array}$ \\
\hline BCA27 & $261-298$ & 16 & 9.0 & 0.67 & 0.90 & 0.88 & 0.922 & + & - & - & - & - \\
\hline BCA52 & $186-226$ & 12 & 8.9 & 0.41 & 0.90 & 0.88 & 0.013 & + & - & - & - & - \\
\hline BCA65 & $146-152$ & 2 & 1.1 & 0.10 & 0.10 & 0.09 & 0.746 & - & - & - & - & - \\
\hline BCA68 & $110-138$ & 6 & 2.1 & 0.47 & 0.53 & 0.49 & 0.363 & + & + & + & - & - \\
\hline BCA70 & $320-378$ & 9 & 7.3 & 0.60 & 0.88 & 0.85 & $0.003 *$ & - & - & - & - & - \\
\hline BCA83 & $156-164$ & 3 & 2.1 & 0.47 & 0.54 & 0.47 & 0.105 & + & - & - & - & - \\
\hline BCA84 & $102-122$ & 6 & 2.3 & 0.28 & 0.57 & 0.53 & 0.011 & - & - & - & - & - \\
\hline GA5 & $211-221$ & 4 & 1.4 & 0.13 & 0.27 & 0.25 & $0.002 *$ & + & - & - & - & - \\
\hline GA13 & $90-96$ & 2 & 1.1 & 0.00 & 0.13 & 0.12 & $0.000^{*}$ & - & - & - & - & - \\
\hline GA31 & $180-194$ & 3 & 1.6 & 0.23 & 0.39 & 0.32 & 0.113 & - & - & - & - & - \\
\hline GA34 & $121-146$ & 10 & 4.8 & 0.32 & 0.80 & 0.76 & 0.017 & + & + & - & - & - \\
\hline GA94 & $129-154$ & 14 & 10.3 & 0.53 & 0.92 & 0.90 & 0.463 & - & - & - & - & - \\
\hline
\end{tabular}


Cross-amplification of the southern flounder markers was examined in five other flatfish species. The results showed that six markers $(50 \%)$ successfully amplified P. olivaceus DNAs, two markers (16.7\%) yielded amplifications in V. variegatus, only one marker $(8.3 \%)$ showed amplifications in V. moseri, while none of them amplified $S$. maximus and C. semilaevis DNAs (Table 3). The results indicated that half of the microsatellite markers could successfully amplify in different species within the genus Paralichthys, only a few markers could obtain cross-species amplifications in the family Pleuronectidae, and all microsatellite markers were unable to cross-amplify in species from the families Scophthalmidae and Cynoglossidae. This indicated that the microsatellite markers developed in P. lethostigma could be used for related species in the genus Paralichthys. All of the polymorphic markers would be useful for the future genetic breeding and the assessment of genetic variation within Paralichthys.

\section{ACKNOWLEDGMENTS}

Research supported by the China Agriculture Research System (\#CARS-50) and the National High Technology Research and Development Program, China (\#2012AA10A413). We thank Dr. Wade O. Wanatabe for providing fin clip samples of wild southern flounder population at the Center for Marine Science, University of North Carolina Wilmington, USA.

\section{REFERENCES}

Bai GF and Lin Y (2006). Southern flounder cultured in fresh water pond. Fish. Sci. 25: 420-421.

Botstein D, White RL, Skolnick M and Davis RW (1980). Construction of a genetic linkage map in man using restriction fragment length polymorphisms. Am. J. Hum. Genet. 32: 314-331.

Froeschke BF, Sterba-Boatwtight B and Stunz GW (2011). Assessing southern flounder (Paralichthys lethostigma) longterm population trends in the northern Gulf of Mexico using time series analyses. Fish. Res. 108: 291-298.

Jenkins WE and Smith TIJ (1999). Pond nursery production of southern flounder (Paralichthys lethostigma) and weaning to commercial diets. Aquaculture 176: 173-180.

Li Q and Wan JM (2005). SSRHunter: development of a local searching software for SSR sites. Yi Chuan 27: 808-810.

Liu XZ, Sun ZZ, Tian JB, Liang Y, et al. (2007). Progress in reproductive biology and seedlings production of southern flounder Paralichthys lethostigma. Fish. Modernization 2: 14-17.

PREMIER Biosoft International (2009). Primer Premier Version 5.0 for Windows and Power Macintosh, Palo Alto. Available at [www.premierbiosoft.com/DATAFILES/PR500Manual.pdf]. Accessed June 20, 2011.

Renshaw MA, Blandon IR and Gold JR (2012). Isolation and characterization of microsatellite markers in southern flounder, Paralichthys lethostigma. Conserv. Genet. Resour. 5: 35-38.

Rice WR (1989). Analyzing tables of statistical tests. Evolution 43: 223-225.

Rousset F (2008). Genepop'007: a complete re-implementation of the Genepop software for Windows and Linux. Mol. Ecol. Resour. 8: 103-106.

Shao CW, Liao X and Chen SL (2008). PERMANENT GENETIC RESOURCES: Isolation and characterization of microsatellite DNA loci from the southern flounder, Paralichthys lethostigma. Mol. Ecol. Resour. 8: 381-383.

Smith TIJ, Denson MR, Heyward LD, Jenkins WE, et al. (1999a). Salinity effects on early life stages of southern flounder Paralichthys lethostigma. J. World Aquacult. Soc. 30: 236-244.

Smith TIJ, McVey DC, Jenkins WE, Denson MR, et al. (1999b). Broodstock management and spawning of southern flounder, Paralichthys lethostigma. Aquaculture 176: 87-99.

Taggart JB, Hynes RA, Prodöhl PA and Ferguson A (1992). A simplified protocol for routine total DNA isolation from salmonid fishes. J. Fish Biol. 40: 963-965.

Watanabe WO, Woolridge CA and Daniels HV (2006). Progress toward year-round spawning of southern flounder broodstock by manipulation of photoperiod and temperature. J. World Aquacult. Soc. 37: 256-272.

Weber JL (1990). Informativeness of human (dC-dA)n.(dG-dT)n polymorphisms. Genomics 7: 524-530

Yeh FC, Yang RC and Boyle T (1999). POPGENE Version 1.31: Microsoft Windows - Based Freeware for Population Genetic Analysis. University of Alberta and Centre for International Forestry Research, Edmonton. Available at [http://www.ualberta.ca/ fyeh/popgene_download.html]. Accessed April 20, 2011.

Zane L, Bargelloni L and Patarnello T (2002). Strategies for microsatellite isolation: a review. Mol. Ecol. 11: 1-16. 